\author{
A.R. Yeshkeyev ${ }^{*}$, N.M. Mussina \\ Buketov Karaganda University, Karaganda, Kazakhstan \\ (E-mail: aibat.kz@gmail.com,nazerke170493@mail.ru)
}

\title{
An algebra of the central types of the mutually model-consistent fragments
}

\begin{abstract}
In this paper, the model-theoretical properties of the algebra of central types of mutually model-consistent fragments are considered. Also, the connections between the center and the Jonsson theory in the permissible signature enrichment are shown, and within the framework of such enrichment, instead of some complete theory under consideration, we can obtain some complete 1-type, and we will call this type the central type, while the theories under consideration will be hereditary. Our work is divided into 3 sections: 1) the outer and inner worlds of the existentially closed model of the Jonsson theory (and the feature between these worlds is considered for two existentially closed models of this theory); 2) the $\lambda$-comparison of two existentially closed models (the Schroeder-Bernstein problem is adapted to the study of Jonsson theories in the form of a $J S B$-problem); 3) an algebra of central types (we carry over the results of Section 2 for the algebra $(\operatorname{Fr}(\bar{C}), \times)$, where $\bar{C}$ is the semantic model of the theory $\bar{T})$. Also in this article, the following new concepts have been introduced: the outer and inner worlds of one existentially closed model of the same theory (as well as the world of this model), a totally model-consistent Jonsson theory. The main result of our work shows that the properties of the algebra of Jonsson theories for the product of theories are used as an application to the central types of fixed enrichment. And it is easy to see from the definitions of the product of theories and hybrids that these concepts coincide if the product of two Jonsson theories gives a Jonsson theory.
\end{abstract}

Keywords: Jonsson theory, central types, $\varphi(x)$-set, outer world, inner world, $\lambda$-comparison, totally modelconsistent theory, fragment, algebra of the central types, semantical model.

In this article, we will consider an algebra that is related to the central types of some fixed Jonsson spectrum; more precisely, we work in one of the cosemanticness classes of some Jonsson spectrum. Moreover, the center of this class is a perfect, totally model-consistent theory. One of the special cases of the $J S B$-problem is also considered within the framework of the study of the class of existentially closed models of some fixed Jonsson theory. The problems related to the description of the syntactic and semantic properties of the Jonsson spectrum $J \operatorname{Sp}(A)$, where $A$ is an arbitrary model of an arbitrary signature, are new problems that appeared in the study of the cosemanticness properties of fixed Jonsson theories $[1 ; 80]$. The works related to this topic include the following works [2-5].

The central idea that led to this article is the idea of defining an operation between complete theories. As far as we know, the first source related to this idea that we were able to find is the work [6]. We would like to note that interest in this topic appeared after the reports of M.I. Bekenov [7] and A.M. Nurakunov [8] at various conferences, where they informed us about their achievements in the study of the algebra of theories concerning the operation introduced in $[6,9]$.

The concept of elementary equivalence between models of a complete theory is an important tool for comparing the similarity of these models, and one of the classical examples of applying this notion to algebra is the Keisler-Shelach theorem on the isomorphism of some ultrapower of elementarily equivalent algebras with each other [10; 363]. In [9] it was shown that elementary equivalence is preserved concerning the Cartesian product. Thus, the above operation, given on theories, preserves elementary equivalence.

The concept of cosemanticness $[11 ; 867]$ is a generalization of the concept of elementary equivalence. And this concept is directly related to the study of the model-theoretical properties of the Jonsson theory. As follows from the definition, Jonsson theories are, generally speaking, incomplete, so we cannot directly transfer the concept of an operation between Jonsson theories as a Cartesian product of their models, as announced in the

\footnotetext{
${ }^{*}$ Corresponding author.

E-mail: aibat.kz@gmail.com
} 
above reports [7], [8]. In particular, it should be noted that we are not working with the entire class of models of the fixed Jonsson theory, but only with the class of their existentially closed models. And there are 3 reasons for this: 1) as is well known from the definition of Jonsson's theory, any of its models is isomorphically embedded in some existentially closed model of this theory; 2) in the case of the perfectness of the considered Jonsson theory the class of its existentially closed models coincides with the class of all models of the center of considered Jonsson theory; 3) the semantic model of the considered Jonsson theory is an existentially closed model of this theory. Therefore, we will consider the concept of cosemanticness between the existentially closed models of this Jonsson theory.

The next aspect of the difference between our approach to the algebra of the considered Jonsson theories from the statement of the problem in the reports [7], [8] is the fact that we will deal with central types of a fixed Jonsson spectrum, that is, we will work in some enrichment of the original language.

The concept of a Jonsson spectrum was directly related to the concept of cosemanticness, both between models and theories. The definition of cosemanticness between models and between theories can be found in the following reference [12]. Some interest is the consideration of special definable subsets of the semantic model fixed Jonsson theory. In this regard, we draw the reader's attention to the following articles [13-15], which use various approaches in adapting the classical concepts of the model theory of arising in the study of complete theories to Jonsson theories.

In [6], the product of two theories was considered, and it was shown that this product preserves the stability properties in the product, if such are the factors.

It is well known that the concept of cosemanticness generalizes the concept of elementary equivalence, that is, if two models of some Jonsson theory of an arbitrary signature are elementarily equivalent to each other, then they are cosemantic to each other. Moreover, the notion of cosemanticness of two models is related to the notion of a Jonsson spectrum as follows: models $A \bowtie B$ if $J S p(A)=J S p(B)$.

Our task in this article is to adapt the above properties of the considered algebra of complete theories to study the model-theoretical properties of some fixed Jonsson theory.

Using the fact that the Jonsson theory $T$ is a special case of inductive theories, we note that the class $E_{T}$ is always not empty, and also that in inductive theory any model from the class ModT is isomorphically embedded into some model from the class $E_{T}$.

\section{The outer and inner worlds of the existentially closed model of the Jonsson theory}

The following definition defines the inner world $\left(I W_{T}(A)\right)$ of the model $A$ of the Jonsson theory $T$ when $A \in E_{T}$.

Definition 1. Let $T$ be an arbitrary Jonsson theory. $I W_{T}(A)=\left\{A^{\prime} \in E_{T} \mid f\right.$ is isomorphism, $f: A^{\prime} \rightarrow A$, $\left.A \in E_{T}\right\}$ is called the inner world of the model $A$ for $T$.

The following definition defines the outer world $\left(O W_{T}(A)\right)$ of the model $A$ of the Jonsson theory $T$ when $A \in E_{T}$.

Definition 2. Let $T$ be an arbitrary Jonsson theory. $O W_{T}(A)=\left\{B \in E_{T}\right.$ : there exist $\left.A^{\prime} \cong A, A^{\prime} \subseteq B\right\}$ is called the outer world of the model $A$ for $T$.

And just the world of the existentially closed model $A$ will be the following set

$$
W_{T}(A)=I W_{T}(A) \cup O W_{T}(A) .
$$

Note that the above definitions can connect two different existentially closed models in the case of a convex theory. As the following theorem is true.

Theorem 1. Let $T$ be the perfect, strong convex Jonsson theory. Since for any models $A, B \in E_{T}$ the following is true:

1) $O W_{T}(A) \cap O W_{T}(B) \neq \emptyset$

2) $I W_{T}(A) \cap I W_{T}(B) \neq \emptyset$.

Proof. By virtue of the perfectness of the theory $T, E_{T}=\operatorname{Mod} T^{*}$. And all existentially closed models of the theory $T$ are models of the center of the theory $T$, therefore property 1 ) is true due to the fact that models $A$ and $B$ are existentially closed submodels of the semantic model $C$, where $C$ - semantic model of the theory $T$. Due to the strongly convexity of the theory $T$, the intersection of any two models is not empty. Condition 2) is trivial and is performed due to the joint embedding property $(J E P)$ of the theory $T$. In particular, the model $C$ satisfies these conditions due to the $T^{+}$universality of the model $C$. 


\section{The $\lambda$-comparison of two existentially closed models}

In model theory, the formulation of the following problem is well known, which is called the SchroderBernstein problem $(S B)$ [16]. This question concerns the isomorphism of two structures, which are mutually elementary embedded in each other. This topic was adapted to the study of Jonsson theories in the form of a $J S B$-problem. In particular, one can refer to [11], where the $J S B$-problem is studied in the framework of Jonsson Abelian groups.

In this section, we will consider a special case of this problem, namely, the $\lambda$-comparison of two existentially closed models of Jonsson theory.

Definition 3. Let $T$ be a Jonsson theory. Let $\omega \leq \lambda \leq \mu, A$ and $B$ be existentially closed models of the theory T. $|A|=|B|=|\mu|$. Models $A$ and $B$ will be called the $\lambda$-comparable if for any existentially closed submodel $A^{\prime}$ of a model $A$, such that $\left|A^{\prime}\right| \leq \lambda$, it is true that $A^{\prime}$ is an existentially closed submodel of $B$, and for any existentially closed submodel $B^{\prime}$ of a model $B$, such that $\left|B^{\prime}\right| \leq \lambda$, it is true that $B^{\prime}$ is an existentially closed submodel of $A$.

It is clear that the above definition defines an equivalence relation on the set of all existentially closed models of the considered Jonsson theory. Therefore, the following spectral definition of the number of model classes makes sense.

Definition 4. Let $T$ be a Jonsson theory, $\omega \leq \lambda \leq \mu . N\left(E_{T}^{\lambda, \mu}\right)$ calculates the number of classes of existentially closed models of Jonsson theory of cardinality $\mu$ concerning the $\lambda$-comparison relation.

Definition 5. Let $I W_{T}^{\lambda}(A)$ be the set of all models from $I W_{T}(A)$, whose cardinality does not exceed $\lambda$.

Theorem 2. Let $T$ be $\exists$-complete, Jonsson theory, and for some $\omega \leq \lambda \leq \mu$ holds $N\left(E_{T}^{\lambda, \mu}\right)=1$. Then the theory $T^{*}$ is model complete.

Proof. Let there exist $\omega \leq \lambda \leq \mu$, such that $N\left(E_{T}^{\lambda, \mu}\right)=1$. It means that for any two models $A, B$, $|A|=|B|=|\mu|, A, B \in E_{T}, I W_{T}^{\lambda}(A)=I W_{T}^{\lambda}(B)$. Using the fact that all models from $I W_{T}^{\lambda}(A)$ are isomorphic to each other due to the condition $N\left(E_{T}^{\lambda, \mu}\right)=1$, we fix an isomorphism between any two models $M_{1}, M_{2}$ from $I W_{T}^{\lambda}(A)$ and $I W_{T}^{\lambda}(B)$. Further, in view of the $\exists$-completeness of the theory $T$ and the $k^{+}$-homogeneity of the semantic model $C$ of the theory $T$, we can extend this isomorphism to an automorphism $C$.It follows that the outer worlds are $O W_{T}\left(M_{1}\right) \uparrow A=O W_{T}\left(M_{2}\right) \uparrow B$. Since $W_{T}\left(M_{1}\right)=W_{T}\left(M_{2}\right)$, we have that $A \cong B$. Those in cardinality $\mu$ he theory $T$ in the class $E_{T}$ has only one model up to isomorphism, the theory $T$ is $\mu$-categorical, which means that it is $T$-perfect. In this case, that $T^{*}$ is a model companion of the theory $T$, and respectively, $T^{*}$ is model complete.

Let us give the necessary definitions of concepts from the above sources and list the results announced in the reports [7], [8].

In what follows, let $T$ be some fixed perfect Jonsson theory, $C$ is a semantic model of the theory $T$.

The product of two complete theories in an arbitrary first-order language $L$ is defined as follows.

Let us give the definition of a product of fixed mutually model-consistent Jonsson theories in a countable language of an arbitrary signature $\sigma$.

Definition 6 . Let $T_{1}, T_{2}$ be Jonsson theories and $T_{1}, T_{2}$ mutually model-consistent.Then we define $T_{1} \times T_{2}$ as the following theory: $T h_{\forall \exists}\left(C_{1} \times C_{2}\right)$, where $C_{1}, C_{2}$ are semantic models of Jonsson theories $T_{1}, T_{2}$, respectively in cardinality $2^{k}$, where $k \geq \omega$.

In particular, if we consider Jonsson's horn theory, then since it is not necessarily complete, we can isolate all of its completion. And as an example of an operation for complete theories, we can consider an operation between completions on the set of all completions.

Due to the fact that the semantic model of some Jonsson theory, which specifies the cosemanticness of these two theories, is existentially closed, it does not yet follow that the Cartesian product of two existentially closed submodels of the semantic model will be an existentially closed submodel of this semantic model.

If $X$ is an arbitrary definable subset of the semantic model $C$ of the Jonsson theory $T$ and its closure $\operatorname{cl}(X)=M$ in some pregeometry given on the Boolean $C$, then the following Jonsson theory is $T h_{\forall \exists}(M)$, denoted by $\operatorname{Fr}(X)$, we will call a fragment in the theory $T$. It is easy to see that if $M \in E_{T}$, then $\operatorname{Fr}(X)$ is always Jonsson theory. In this article, we do not consider the content of the set $X$.

Let $\operatorname{Fr}(C)$ denote the set of all fragments in the theory $T$.

Definition \%. A Jonsson theory $T$ is called totally model-consistent if any of its two fragments $\operatorname{Fr}\left(X_{1}\right)$, $\operatorname{Fr}\left(X_{2}\right) \in \operatorname{Fr}(C)$ are mutually model-consistent, where $X_{1}, X_{2}$ are some definable subsets of $C$.

It seems to us a great prospect is filled with real meaning that the concept of definability of a subset of the semantic model through the concept of $\varphi(x)$-set. For example, when $\varphi(x)$ expresses: $A P A$-transcendence, 
various kinds of atomicity and primeness, strongly minimality, Jonssonness. And finally, the description of the closure of the $\varphi(x)$-set will be obtained through the $\varphi(x)$-rheostat [17].

In what follows, we will work within the framework of a fixed totally model-consistent Jonsson theory. It is clear that in this case, the question arises: is the cosemanticness class of Jonsson theories perfect if its center is model-consistent? That is, the question arises: in which case of the center will the following theorem be true?

Theorem 3. If the fixed center of some cosemanticness class of the Jonsson spectrum is totally modelconsistent, then its semantic model is saturated.

The essence of the question lies in filling with the meaning of the word fixed.

Definition 8. For each fragment $\nabla$ from the Jonsson theory $T$ select the following set $N \nabla=\{\Delta \mid \Delta \in$ $\in \operatorname{Fr}(C), \Delta \times \nabla=\nabla\}$. Let $D \subseteq \operatorname{Fr}(C)$. If $D=N \nabla$ for some $\nabla \in \operatorname{Fr}(C)$, then $D$ is called a definable set of the theory $\nabla$.

Let $\Delta_{1}, \Delta_{2}, \ldots \Delta_{n}, \Delta \in \operatorname{Fr}(C)$.

Consequence 1. For any $\Delta \in \operatorname{Fr}(C), N \Delta$ is non-empty and closed with respect to finite products.

Proof. $E$ is the theory of one-element model, then $E \times \Delta=\Delta$. Hence, $N \Delta$ is not empty. Let $\Delta_{1}, \ldots, \Delta_{n}$ be from $N \Delta$, then $\Delta_{1} \times \ldots \times \Delta_{n} \times \Delta=\Delta$, that is, closed with respect to finite products.

Remark 1. Generally speaking, the theory $\Delta$ can not belong to $N \Delta$, and $N \Delta$ can not be closed with respect to infinite products, and there are various $\nabla_{1}, \nabla_{2}$, such that $N \nabla_{1}=N \nabla_{2}$, that is, they have the same definable set $N$.

Definition 9. If $\Delta_{1} \times \Delta_{2}=\Delta_{2}$, then we will write $\Delta_{2}$ absorbs $\Delta_{1} . \Delta$ is called an idempotent if $\Delta \times \Delta=\Delta$.

Definition 10. A set $D \subseteq \operatorname{Fr}(C)$ is called a definable idempotent if there exists an idempotent $\Delta$, such that $N \Delta=D$.

Jonsson's version of Weinstein's theorem [10; 416].

Theorem 4. Let $A, B, C \in E_{T}$. If $A \bowtie(A \times B \times C)$, then $A \bowtie(A \times B)$ ( $\bowtie$ is cosmanticness of models).

Proof. The elementary equivalence of the two models implies that they are cosemantic.

Theorem 5. If $\Delta_{1}=\Delta_{1} \times \Delta_{2} \times \Delta_{3}$, then $\Delta_{1}=\Delta_{1} \times \Delta_{2}$.

Proof. Follows from Theorem 5 and Theorem 4.

Theorem 6 (Vaught [10; 403]). A sentence in the language $L$ is stable with respect to infinite direct products of algebraic systems if it is stable with respect to any finite subproducts of this infinite product.

Theorem \%. If $D \subseteq \operatorname{Fr}(C)$, and $D$ is closed under infinite products, then there is a unique idempotent $\Delta \in D$, that absorbs any element from $D$.

For example, the set of all theories that are complete extensions of the theory of some quasivariety are absorbed by the corresponding idempotent, but this idempotent may not define this set.

Theorem 8. Let $D \subseteq \operatorname{Fr}(C)$, and $D$ is a definable set closed with respect to infinite products, then there is a unique idempotent $\Delta \in D$ such that $D$ is definable by this idempotent.

Proof. Let $D=N \Delta$ for some theory $\Delta$. By Theorem 7 , there is an idempotent $\Delta_{2}$, which absorbs all elements from $D$. Idempotent $\Delta_{2}$ defines the set $D$. Indeed, if for some theory $\Delta_{1}$ holds $\Delta_{2} \times \Delta_{1}=\Delta_{2}$, then $\Delta \times \Delta_{2} \times \Delta_{1}=\Delta$. This means that $\Delta \times \Delta_{1}=\Delta$. That is, $\Delta_{1} \in D$.

Theorem 9. If $\Delta$ is idempotent, then its any power is $\Delta^{k}=\Delta$.

Proof. The proof follows from the above definitions.

Theorem 10. If $\Delta$ is idempotent, then $N \Delta$ is closed with respect to the products.

Proof. Let $N \subseteq N \Delta$ and $N=\left\{\Delta_{i} \mid i \in I\right\}$. Take the product of all $\Delta_{i} \in N$. We denote this product by $P$. Since $\Delta$ is idempotent, we can write $\Delta=\Delta \times \Delta \times \ldots=\left(\Delta_{1} \times \Delta\right) \times\left(\Delta_{2} \times \Delta\right) \times \ldots=\Delta_{1} \times \Delta_{2} \times \ldots \times \Delta \times \Delta=P \times \Delta$. То есть $P \in N \Delta$.

If we use the well-known theorem: „For any families $\left\{A_{i} \mid i \in I\right\},\left\{B_{i} \mid i \in I\right\}$ of algebraic systems and any filter $D$ over $I$, holds $\prod_{i \in I}\left(A_{i} \times B_{i}\right) / D=\prod_{i \in I} A_{i} / D \times \prod_{i \in I} B_{i} / D$ ". The following is true.

All the remaining statements in this section (Theorem 11-17, Corollary 2-3) are Jonsson analogs of the corresponding results from the unpublished paper [18].

Theorem 11. If $\Delta$ is idempotent, then $N \Delta$ is an axiomatizable theory.

Theorem 12. Let $I d=\{\Delta \mid \Delta \in \operatorname{Fr}(C), \Delta$-idempotent $\}$. Id with the product operation forms a commutative semigroup of idempotents with identity.

Corollary 2. The semigroup of idempotents $H$ is isomorphically embeddable into a suitable power of the semigroup $J$, where $J$ is the semigroup with base set $\{0,1\}$ and the corresponding operation.

Thus, it is possible to represent idempotents as sequences of zeros and ones.

Definition 11. We will write $\Delta_{1} \leq \Delta_{2}$, if and only if $\Delta_{1} \times \Delta_{2}=\Delta_{2}$.

Corollary 3. The relation $\leq$ on the set $\operatorname{Fr}(C)$ is a partial order with the largest and the smallest elements.

Theorem 13. Let $\Delta_{1}, \Delta_{2} \in I d$. The set $N \nabla_{1} \cap N \nabla_{2}$ is definable by an idempotent. 
Theorem 14. Let $\Delta_{1}, \Delta_{2}, \Delta_{3} \in I d$ and $\Delta_{1} \leq \Delta_{3}, \Delta_{2} \leq \Delta_{3}$. Then $\Delta_{1} \times \Delta_{2} \leq \Delta_{3}$.

Definition 12. On the set $I d$ we introduce the operations of union and intersection. Let $\Delta_{1}, \Delta_{2} \in I d$. $\Delta_{1} \cup \Delta_{2}=\Delta_{1} \times \Delta_{2}$, and $\Delta_{1} \cap \Delta_{2}=\Delta$, where $\Delta$ is from the proof of Theorem 13 .

Theorem 15. The set $I d$ with operations $\cup$ and $\cap$ forms a complete lattice.

Theorem 16. Each variety is associated with its unique defining idempotent.

Theorem 1\%. The set of definable quasivarieties with respect to the introduced operations $\cup$ and $\cap$ form a complete lattice.

\section{An algebra of the central types}

Let us give the necessary definitions related to a special kind of enrichment of the Jonsson theory, which preserves certain properties. Within the framework of such enrichment, as a consequence of the laws of the logic of the predicate calculus, instead of the considered some complete theory, we can obtain a maximally consistent set of formulas, i.e. some complete 1-type. We will call this type the central type.

The main idea of this section is to use, as an application to central types of fixed enrichment, the properties of the algebra of Jonsson theories with respect to the products of theories.

Let $T$ be a fixed hereditary Jonsson theory in the language $L$ of some signature $\sigma, C$ is a semantic model of this theory, $\sigma^{\prime}=\sigma \bigcup\{P\} \bigcup\{c\}$, take the set $A$, as a subset of $C$.

Let $\bar{T}=T \bigcup T h_{\forall \exists}\left(C, c_{a}\right)_{a \in A} \bigcup\{P(c)\} \bigcup\{P, \subseteq\}$. Here $\{P, \subseteq\}$ is an infinite set of sentences that reflect the following fact: „An interpretation of the symbol $P$ will be an existentially closed submodel on $L$ of signature $\sigma^{\prime \prime \prime}$, thus, we obtain that the interpretation of the symbol $P$ is a solution of the equation $P(C)=M, M \in E_{T}$ in $L$ of signature $\sigma^{\prime}$.

Due to the fact that not all Jonsson theories in enrichment preserve the property of being a Jonsson theory, we will work in the class of hereditary Jonsson theories. "What is it?" - give the following definitions.

Definition 13. An enrichment $\bar{T}$ of the Jonsson theory $T$ is said to be permissible if any $\nabla$-type (it mean that $\nabla$ subset of language $L_{\sigma}$ and any formula from this type belongs to $\nabla$ ) in this enrichment is definable in the framework of $\bar{T}_{\Gamma^{-} \text {-stability. }}$

Definition 14. The Jonsson theory is said to be hereditary, if in any of its permissible enrichment, any expansion of it in this enrichment will be Jonsson theory.

Let $T$ be a fixed hereditary Jonsson theory that is totally model-consistent, $C$ its semantic model, $\operatorname{Fr}(C)$ the set of all fragments in the theory $T$. On the set $\operatorname{Fr}(C)$ we define the operation $(\times)$, which will be the algebra $(\operatorname{Fr}(C), \times)$. And it forms a commutative semigroup of idempotents with unity, and the set of idempotents with operations $\cup$ and $\cap$ forms a complete lattice. Also applicable to the algebra $(\operatorname{Fr}(\bar{C}), \times)$, where $\bar{C}$ is the semantic model of the theory $\bar{T}$. And we have the following results when considering this algebra.

The operation of multiplying fragments from $\operatorname{Fr}(C)$ induces the operation of multiplication in $\operatorname{Fr}(\bar{C})$, and we can notice that $\operatorname{Fr}(\bar{C})$, as well as $\operatorname{Fr}(C)$, is a commutative semigroup for multiplication of fragments in the theory $\bar{T}$.

Since the considered theory $T$ is totally model-consistent, the product of two fragments from $\operatorname{Fr}(C)$ is a theory from $\operatorname{Fr}(C)$, that is, $\operatorname{Fr}(C)$ is the cosemantic class of the Jonsson spectrum of some model of the signature of the theory $T$.

It is clear that this topic, namely, the algebraization of the field of activity of work with central types, is closely to the questions arising in the study of Jonsson's theories. Let's dwell on one of them. This question concerns hybrids of Jonsson theories [19-21].

It is easy to see from the definitions of the product of theories and hybrids that these concepts coincide if the product of two Jonsson theories gives a Jonsson theory. In this case, the product of the central types of Jonsson theories differs from the concept of a hybrid in the following way: 1) to define the central type, some enrichment of the signature is necessary, difference to hybrids of Jonsson theories; 2) a hybrid of Jonsson's theories can be of 2 types (the first and second types), while the second type of hybrid depends on the Jonsson theories of two different signatures, difference to the product of Jonsson theories.

\section{Acknowledgments}

This work was supported by the Science Committee of the Ministry of Education and Science of the Republic of Kazakhstan (grant AP09260237). 


\section{References}

1 Barwise J. Ed., Handbook of mathematical logic. Part 1, Model Theory / J. Barwise. - M.: Science, 1982.

2 Yeshkeyev A.R. Properties of lattices of the existential formulas of Jonsson fragments / A.R. Yeshkeyev, M.T. Kasymetova // Bulletin of the Karaganda University. Mathematics series. - 2015. - 79. - № 3. P. 25-32.

3 Poizat B. Positive Jonsson Theories / B. Poizat, A.R. Yeshkeyev // Logica Universalis. — 2018. - 12. № 1-2. - P. 101-127.

4 Yeshkeyev A.R. del-cl-atomic and prime sets / A.R. Yeshkeyev, A.K. Issayeva // Bulletin of the Karaganda University. Mathematics series. - 2019. - 93. - № 1. - P. 88-94. DOI: 10.31489/2019M1/88-94

5 Yeshkeyev A.R. The Properties of Similarity for Jonsson's Theories and Their Models / A.R. Yeshkeyev // Bulletin of the Karaganda University. Mathematics series. - 2015. - 80. — № 4. - P. 52-59.

6 Wierzejewski J. On stability and products / J. Wierzejewski // Fundamenta Mathematicae. - 1976. 93. - P. 81-95.

7 Bekenov M.I. Semigroup of theories and lattices of idempotent elements / M.I. Bekenov // Program and Abstracts of The 16th Asian Logic Conference, Nur-Sultan. - 2019. - P. 36-37.

8 Нуракунов А.М. Полугруппа теорий и ее решетка идемпотентных теорий / А.М. Нуракунов, М.И. Бекенов // Мальцевские чтения-2020. - Новосибирск, 2020.

9 Weinstein J.M. First order properties preserved by direct product / J.M. Weinstein // Ph.D. thesis. Univ. Wisconsin, Madison, Wis. - 1965.

10 Кейслер Х.Дж. Теория моделей / Х.Дж. Кейслер, Ч.Ч. Чэн. - М.: Мир, 1977. - 614 с.

11 Ешкеев А.Р. $J S p$-косемантичность и $J S B$-свойство абелевых групп [Электронный ресурс] А.Р. Ешкеев, О.И. Ульбрихт // Siberian Electronic Mathematical Reports. - 2016. - 13. - C. 861-874. Режим доступа: http://semr.math.nsc.r Doi: 10.17377/semi.2016.13.068

12 Ешкеев А.Р. Йонсоновские теории и их классы моделей: моногр. / А.Р. Ешкеев, М.Т. Касыметова. - Караганда: Изд-во КарГУ, 2016. - 370 с.

13 Yeshkeyev A.R. The atomic definable subsets of semantic model / A.R. Yeshkeyev, N.M. Mussina, A.K. Issayeva // Bulletin of the Karaganda University. Mathematics series. - 2019. — 94. - № 2. P. 84-91. DOI 10.31489/2019M2/84-91

14 Yeshkeyev A.R. Companions of the fragments in the Jonsson enrichment / A.R. Yeshkeyev // Bulletin of the Karaganda University. Mathematics series. — 2017. — 85. — № 1. - P. 41-45. DOI: 10.31489/2017M1/4145

15 Ешкеев A.P. JSp-косемантичность $R$-модулей [Электронный ресурс] / A.P. Ешкеев, О.И. Ульбрихт // Siberian electronics mathematical reports. - 2019. - 16. - С. 1233-1244. - Режим доступа: http://semr.math.nsc.ru DOI: 10.33048/semi.2019.16.084

16 Goodrick J. The Schröder-Bernstein property for a-saturated models / J. Goodrick, M.C. Laskowski // Proc. AMS - 2014. - 142. - 3. - P. 1013-1023. Zbl 06268279

17 Yeshkeyev A.R. Method of the rheostat for studying properties of fragments of theoretical sets A.R. Yeshkeyev // Bulletin of the Karaganda University. Mathematics series. - 2020. - 100. - № 4. P. 152-159. DOI 10.31489/2020M4/152-159

18 Bekenov M.I. Semigroup of theories and its lattice of idempotent elements / M.I. Bekenov, A.M. Nurakunov // Algebra and Logic. - 2021.

19 Yeshkeyev A.R. Properties of hybrids of Jonsson theories / A.R. Yeshkeyev, N.M. Mussina // Bulletin of the Karaganda University. Mathematics series. - 2018. - 92. - № 4. - P. 99-104. DOI: 10.31489 /2018M4/99-104

20 Yeshkeyev A.R. Small models of hybrids for special subclasses of Jonsson theories / A.R. Yeshkeyev, N.M. Mussina // Bulletin of the Karaganda University. Mathematics series. - 2019. - 95. - № 3. P. 68-73.

21 Yeshkeyev A.R. Chains of existentially closed models of positive (n(1), n(2))-Jonsson theories / A.R. Yeshkeyev, M.T. Omarova // Bulletin of the Karaganda University. Mathematics series. - 2019. 96. 一 № 4. - P. 69-74. DOI 10.31489/2019M4/69-74 
А.Р. Ешкеев, Н.М. Мусина

\title{
Өзара модельді-үйлесімді фрагменттерінің централдық типтерінің алгебрасы
}

\begin{abstract}
Мақалада өзара модельді-үйлесімді фрагменттердің централдық типтерінің алгебрасының модельді-теоретикалық қасиеттері қарастырылған. Централдық және йонсондық теорияның байытылған сигнатурасының байланыстары да көрсетілген және осындай байыту аясында қарастырылған кейбір толық теорияның орнына авторлар толық 1-типті алған және бұл типті централдық тип деп атап, ал теориялардың орнына мұралы теорияларды қарастырған. Бұл жұмыс 3 бөлімге бөлінген: 1) йонсондық теорияның экзистенциалды тұйық моделінің сыртқы және ішкі әлемдері (берілген теорияның екі экзистенциалды тұйық модельдердің әлемдерінің арасындағы ерекшелік қарастырылған); 2) екі экзистенциалды тұйық модельдерді $\lambda$-салыстыру (Шредер-Бернштейн проблемасы йонсондық теорияларды $J S B$-проблемасы түрінде зерттеуге бейімделген); 3) централдық типтердің алгебрасы (2-бөлімнің нәтижелері $(\operatorname{Fr}(\bar{C}), \times)$ алгебрасына көшірілген, мұндағы $\bar{C}-\bar{T}$ теориясының семантикалық моделі). Бұдан басқа мақалада мына тұжырымдамалар енгізілген: теорияның экзистенциалды тұйық моделінің сыртқы және ішкі әлемі (сонымен қатар осы модельдің әлемі), тұтас модельді үйлесімді йонсондық теория. Жұмыстың негізгі нәтижесі көрсеткендей, теориялардың көбейтіндісіне қатысты йонсондық теориялардың алгебрасының қасиеттері бекітілген, байытылған централдық типтеріне қосымша ретінде қолданылады. Теориялардың көбейтіндісі мен гибридтердің анықтамаларынан, егер екі йонсондық теорияның көбейтіндісі йонсондық теорияны берсе, бұл ұғымдардың сәйкес келетіндігін байқау қиын емес.
\end{abstract}

Kiлm сөздер: йонсондық теория, централдық типтер, $\varphi(x)$-жиын, ішкі әлем, сыртқы әлем, $\lambda$-салыстыру, тұтас модельді үйлесімді теория, фрагмент, централдық типтердің алгебрасы, семантикалық модель.

\author{
А.Р. Ешкеев, Н.М. Мусина
}

\section{Алгебра центральных типов взаимно модельно-совместных фрагментов}

\begin{abstract}
В статье рассмотрены теоретико-модельные свойства алгебры центральных типов взаимно модельносовместных фрагментов. Показаны связи между центром и йонсоновской теорией в разрешенном обогащении сигнатуры. В рамках такого обогащения вместо рассматриваемой некоторой полной теории авторы могут получить некоторый полный 1 тип, и он будет называться центральным, при этом рассматриваемые теории будут являться наследственными. Данная работа разбита на 3 параграфа: 1) внешний и внутренний миры экзистенциально замкнутой модели йонсоновской теории (рассмотрена особенность между этими мирами для двух экзистенциально замкнутых моделей данной теории); 2) $\lambda$-сравнение двух экзистенциально замкнутых моделей (проблема Шредера-Бернштэйна адаптирована к изучению йонсоновских теорий в виде $J S B$-проблемы); 3$)$ алгебра центральных типов (результаты параграфа 2 переносятся для алгебры $(\operatorname{Fr}(\bar{C}), \times)$, где $\bar{C}$ - это семантическая модель теории $\bar{T})$. Кроме того, авторами введены следующие понятия: внешний и внутренний миры одной экзистенциально замкнутой модели одной и той же теории (а также мир этой модели); тотально модельно-совместная йонсоновская теория. Главный результат, достигнутый в работе, показывает, что в качестве приложения к центральным типам фиксированного обогащения используются свойства алгебры йонсоновских теорий относительно произведения теорий. И легко заметить из определений произведения теорий и гибридов, что эти понятия совпадают, если произведение двух йонсоновских теорий дает йонсоновскую теорию.
\end{abstract}

Ключевые слова: йонсоновская теория, центральные типы, $\varphi(x)$-множество, внешний мир, внутренний мир, $\lambda$-сравнение, тотально модельно-совместная теория, фрагмент, алгебра центральных типов, семантическая модель. 


\section{References}

1 Barwise, J. (1982). Ed. Handbook of mathematical logic. Part 1, Model Theory. Moscow, Science.

2 Yeshkeyev, A.R., \& Kasymetova, M.T. (2015). Properties of lattices of the existential formulas of Jonsson fragments. Bulletin of the Karaganda University - Mathematics, 79(3), 25-32.

3 Poizat, B., \& Yeshkeyev, A. R. (2018). Positive Jonsson Theories. Logica Universalis, 12(1-2), 101-127.

4 Yeshkeyev, A.R., \& Issayeva, A.K. (2019). del-cl-atomic and prime sets. Bulletin of the Karaganda University - Mathematics, 93(1), 88-94. DOI: 10.31489/2019M1/88-94

5 Yeshkeyev, A.R. (2015). The Properties of Similarity for Jonsson's Theories and Their Models. Bulletin of the Karaganda University - Mathematics, 80(4), 52-59.

6 Wierzejewski, J. (1976). On stability and products. Fundamenta Mathematicae, 93, 81-95.

7 Bekenov, M.I. (2019). Semigroup of theories and lattices of idempotent elements. Program and Abstracts of The 16th Asian Logic Conference, 36-37.

8 Nurakunov, A.M., \& Bekenov, M.I. (2020). Poluhruppa teorii i ee reshetka idempotentnykh teorii [Semigroup of theories and its lattice of idempotent theories]. Maltsevskiie chteniia-2020 - Maltsev Readings2020 [in Russian].

9 Weinstein, J.M. (1965). First order properties preserved by direct product. Ph.D. thesis. Univ. Wisconsin. Madison, Wis.

10 Keisler, H.J., \& Chang, C.C. (1977). Teoriia modelei [Model Theory]. Moscow: Mir [in Russian].

11 Yeshkeyev, A.R., \& Ulbrikht, O.I. (2016). JSp-kosemantichnost i $J S B$-svoistvo abelevykh hrupp [JSp-cosemanticness and JSB property of Abelian groups]. Sibirskie elektronnye matematicheskie izvestiia - Siberian Electronic Mathematical Reports, 13, 861-874 [in Russian].

12 Yeshkeyev, A.R., \& Kassymetova, M.T. (2016). Yonsonovskie teorii i ikh klassy modelei /Jonsson theories and their classes of models]. Karaganda: Izdatelstvo Karahandinskoho universiteta [in Russian].

13 Yeshkeyev A.R., Mussina, N.M., \& Issayeva, A.K. (2019). The atomic definable subsets of semantic model. Bulletin of the Karaganda University - Mathematics, 94(2), 84-91. Doi: 10.31489/2019M2/84-91

14 Yeshkeyev, A.R. (2017). Companions of the fragments in the Jonsson enrichment. Bulletin of the Karaganda University - Mathematics, 85(1), 41-45. Doi: 10.31489/2017M1/41-45

15 Yeshkeyev, A.R., \& Ulbrikht, O.I. (2019). JSp-kosemantichnost $R$-modulei [JSp-cosemanticness of R-modules]. Sibirskie elektronnye matematicheskie izvestiia - Siberian Electronic Mathematical Reports, 16, 1233-1244. DOI: 10.33048/semi.2019.16.084 [in Russian].

16 Goodrick, J., \& Laskowski, M.C. (2014). The Schroder-Bernstein property for a-saturated models Proc. AMS, 142(3), 1013-1023. Zbl 06268279

17 Yeshkeyev, A.R. (2020). Method of the rheostat for studying properties of fragments of theoretical sets. Bulletin of the Karaganda University - Mathematics, 100(4), 152-159. DOI 10.31489/2020M4/152-159

18 Bekenov, M.I., \& Nurakunov, A.M. (2021). Semigroup of theories and its lattice of idempotent elements. Algebra and Logic.

19 Yeshkeyev, A.R., \& Musina, N.M. (2018). Properties of hybrids of Jonsson theories. Bulletin of the Karaganda University - Mathematics, 92(4), 99-104. DOI: 10.31489/2018M4/99-104

20 Yeshkeyev, A.R., \& Mussina, N.M. (2019). Small models of hybrids for special subclasses of Jonsson theories. Bulletin of the Karaganda University - Mathematics, 95(3), 68-73.

21 Yeshkeyev, A.R., \& Omarova, M.T. (2019). Chains of existentially closed models of positive (n(1), n(2))-Jonsson theories. Bulletin of the Karaganda University - Mathematics, 96(4), 69-74. 